\title{
Africa's game changers and the catalysts of social and system innovation
}

Mark Swilling ${ }^{1,2}$

\begin{abstract}
It is widely recognized that many African economies are being transformed by rapid economic growth driven largely by rising demand for the abundant natural resources scattered across the African continent. I critically review the mainstream gamechanging dynamics driving this process, with special reference to a set of influential policy-oriented documents. This is followed by an analysis of less-recognized game-changing dynamics that have, in turn, been affected by the mainstream game-changing dynamics. These less-recognized game-changing dynamics include energy infrastructure challenges in a context of climate change, securing access to water, access to arable soils, slum urbanism, and food security responses. These mainstream and less-recognized game-changing dynamics provide the context for analyzing a range of African actor networks engaged in social and system innovations. I use a transdisciplinary framework to discuss these actor networks and how they construct their understanding of the game changers affecting their programs and actions. Based on a case study of the iShack initiative in Stellenbosch, South Africa, I conclude that social and system innovations will need to be driven by transformation knowledge co-produced by researchers and social actors who can actively link game-changing dynamics that operate at multiple scales with local-level innovations with potential societal impacts.
\end{abstract}

Key Words: African development; social innovation; structural transformation; transdisciplinary research

\section{INTRODUCTION}

"[ W] are trapped in a dual excess: we have an excessive fascination for the inertia of the existing socio-technical systems and an excessive fascination for the total, global and radical nature of the changes that need to be made. The result is a frenetic snail's pace. An apocalypse in slow motion... Changing trajectories means more than a mere apocalypse, and is more demanding than a mere revolution. But where are the passions for change?" Bruno Latour (2010).

A cover of The Economist magazine in 2000 depicted Africa as "the hopeless continent". In 2011, one of its covers depicted Africa as "the hopeful continent", and the magazine has since waxed lyrical about "Africa rising". For eight of the years between 2001 and 2011, sub-Saharan Africa experienced a higher average economic growth rate than East Asian countries. By 2012, Africa accounted for six of the ten fastest growing economies in the world. A spate of data-rich reports by leading consulting companies (Monitor Group 2009, Roxburgh et al. 2010, Ernst \& Young 2011) and financial institutions (International Monetary Fund 2011, World Bank 2011) have reflected this upbeat hype about African growth.

However, leading African financial experts warn that this economic boom is too dependent on extracting and exporting primary resources. This caution was widely expressed at a Ministers of Finance and Economics summit hosted by the African Union in Abuja, Nigeria in March 2014, which I attended. Most exports into non-African markets $(86 \%)$ are still primary resources (United Nations Economic Commission for Africa and African Union 2014). Summit participants appeared to agree that African economies need to implement "structural transformation" to avoid reliance on notoriously unstable global commodity markets. In addition, they expressed the view that only a few employees and shareholders benefitted from extractive industries, which also provided limited backward and forward linkages within domestic economies.
Discussions about the meaning, implications, viability, and institutional modalities of structural transformation dominate Afro-centric academic debates and developmental policy processes. Advocates present structural transformation as pivotal to resolving socioeconomic challenges, in particular, poverty, unemployment, and inequality. Here, I address this debate from the perspective of the TRANSIT project (discussed elsewhere in this special feature), which focuses on the interaction between "game-changing dyanmics" (trends that change the rules of the "game") and system and social innovations (initiatives that change practices and social relations). The analysis explores the potentially catalytic role that transdisciplinary research can play in enabling transformative social innovation by becoming an endogenous activity embedded within a process of building system, target, and transformation knowledge. An overview of key mainstream game-changing dynamics along with lessrecognized game-changing dynamics that are of particular relevance to Africa is provided, followed by an assessment of how these are invoked, perceived, and (re)constructed by system and social innovators. I highlight five social or system innovation initiatives that respond to at least one of these game-changing dynamics. I then provide conclusions about the overall process of transition as the outcome of the interaction between gamechanging dynamics and social or system innovations as revealed by and through transdisciplinary research.

\section{Game-changing dynamics: social and system innovations}

Although the notion of a "game changer" is explored in more depth elsewhere in this special feature, suffice it to state here that the notion of a game changer emerges from a desire to translate the more abstract almost positivist notion of landscape pressures acting beyond human agency as developed in the sustainability transitions approach (Grin et al. 2010) into a contextual dynamic that is perceived by social actors as changing the dominant logics, rules, and conditions of engagement of existing socio-technical regimes at multiple scales (global, national, local; Avelino et al. 2014). However, instead of referring to a game changer as if it is a structural determinant or social actor or anything else that 
implies some kind of inherent agency (as does the notion of game changer), I refer to "game-changing dynamics", which can be defined in constructionist terms as complex processes of change that specific actors invoke to justify their particular set of proposed social and system innovations. Given that there are dominant or mainstream societal actors and more marginal societal actors, it follows that there are also mainstream gamechanging dynamics (as articulated by the mainstream societal actors) and less-recognized game-changing dynamics (as articulated by the more marginal societal actors). I will demonstrate that both mainstream and less-recognized gamechanging dynamics need to be addressed. The mainstream gamechanging dynamics were selected on the basis of the most influential literature in African policy discussions, plus personal experience derived from actual participation in these discussions. The less-recognized game-changing dynamics were selected not because they are the only less-recognized game-changing dynamics; they were the game-changing dynamics referred to by networks of more marginal societal actors who I have had access to over a number of years in various ways. By access, I mean both exposure through direct participation as a transdisciplinary researcher, as in the iShack and Shack/Slum Dwellers International (SDI) cases, or indirectly through discussion and engagement in various fora with three other networks of societal actors. There may, of course, be other equally significant lessrecognized game-changing dynamics such as, for example, the emergence of youth-based urban uprisings (Branch and Mampilly 2015). I make no claim that the less-recognized gamechanging dynamics selected here are the most significant. The claim of significance is made with respect to the mainstream game-changing dynamics that have been selected.

Drawing on recent work on social innovations (Mulgan 2006, Murray et al. 2010, Franz et al. 2012, Haxeltine et al. 2013, Moulaert et al. 2013, Anderson et al. 2014), I make a distinction between social and system innovation. Social innovations refer to a broad range of practices and social relations that break decisively from prevailing approaches to address a social challenge in a new way under conditions of ambiguity and uncertainty. System innovations are similar to social innovations but relate more specifically and more narrowly to institutional challenges, with special reference to governance. This distinction is important because societal actors can organize themselves into new socially innovative networks to visualize, propose, and achieve system innovations. In all cases, whether discussing social or system innovations, actor networks invoke particular conceptions of game-changing dynamics to justify their particular practice or proposed innovations.

\section{Game-changing dynamics: innovation and transdisciplinary research}

The work of Stellenbosch University's Centre for Complex Systems in Transition (CST; see http://www.tsamahub.org.za) focuses on applying emerging global thinking about transdisciplinary research to the African context (Lang et al. 2012, Muhar et al. 2013, Swilling 2014). In particular, the CST aims to merge transdisciplinary case research with indigenous research methods, most clearly articulated by Chilisa (2012). A useful definition of transdisciplinary research is that it is interdisciplinary research that is conducted with, rather than for, society to co-produce socially robust solutions to complex societal problems that can no longer be solved using traditional research approaches (Scholz and Tietje 2002, Hirsch-Hadorn et al. 2006, 2008, Regeer and Bunders 2009). Chilisa's (2012) work on indigenous research methods informs the understanding of who to do research with and why it is necessary to do research with society in ways that connect to indigenous knowledge systems but that also challenge the oppressive tropes embedded in colonial and Western research modes.

Research plays a key role in stimulating and fostering social and system innovations within a wider understanding of gamechanging dynamics. However, what transdisciplinary theory calls system and target knowledge may be necessary but insufficient in these contexts. System knowledge is an understanding of the existing systems. Target knowledge is knowledge that informs policy proposals. Transformation knowledge is qualitatively different because it is knowledge about the complex processes of change that translate collective problem identification into usually localized social innovations that can then, in turn, stimulate system innovations at nonlocal scales. Societal transformations as emergent outcomes of this evolutionary process then become possible. However, researchers need to be embedded in the social processes they are studying to generate transformation knowledge. They thus become social hybrids: activist-researchers accountable to society for producing useful knowledge and accountable to academia for producing scientifically valid knowledge. These two modes of accountability hardly ever align in comfortable and predictable ways.

From this transdisciplinary perspective, the social and system innovations referred to in the five case studies have developed unevenly. Only the iShack case study exemplifies a self-conscious application of the transdisciplinary approach. All the other cases have system innovations in mind derived from target knowledge, with some such as SDI and the African Organic Network (AfroNet) rooting their visions of system innovation in existing social innovations. All five case studies are of actors who invoke specific game-changing dynamics to justify their respective system innovations.

\section{THE CHANGING NATURE OF AFRICA'S DEVELOPMENTAL TRAJECTORIES}

\section{Mainstream game changers}

Commodity prices declined dramatically for a few decades preceding the commodity boom at the turn of the millennium (Fig. 1). Extractive industries outside of the oil sector became increasingly unprofitable and lost skilled human capital to other sectors. Resource-rich developing country governments relaxed controls and created incentives to keep mining at least marginally profitable during this period (Economic Commission for Latin America and the Caribbean 2013). However, they did not change this soft institutional environment when commodity markets boomed. Changing policy and the regulatory environment takes much longer than change in markets. As a result, extractive industries enjoyed super-profits that, in turn, incentivized the increase in exploration budgets from just $>\$ 2$ billion USD in 2003 to $>\$ 21$ billion in 2012 (Fig. 2). It took nearly a decade for developing countries to realize this policy gap and begin to find 
ways to reap the benefits of the boom (Economic Commission for Latin America and the Caribbean 2013). In Africa, this scramble is associated with the rise of the "resource nationalism" discourse and discussions on the role of Sovereign Wealth Funds (A. Pedro, unpublished manuscript). Sovereign Wealth Funds are funds created by sovereign states to manage resource rents generated from resource extractions of various kinds, usually oil, but also metals, forests, etc. This capital is then re-invested to maintain the level of capital that once existed in the form of natural capital.

Fig. 1. Index of international commodity prices January 2000 to May 2013 based on information from the International Monetary Fund. Source: Economic Commission for Latin America and the Caribbean (C) 2013 United Nations

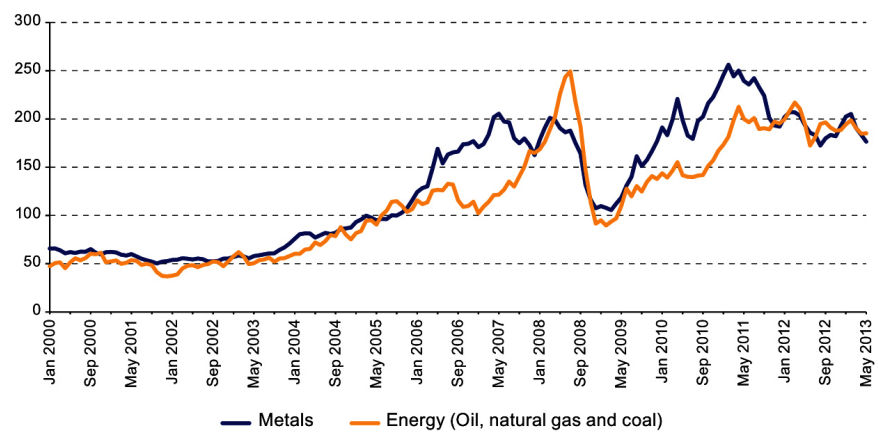

Fig. 2. Distribution ( $\%$ ) of world mineral exploration budget by region or country of destination (on the basis of Centre for Copper and Mining Studies/Metal Economics Group). Source: Economic Commission for Latin America and the Caribbean (C) 2013 United Nations.

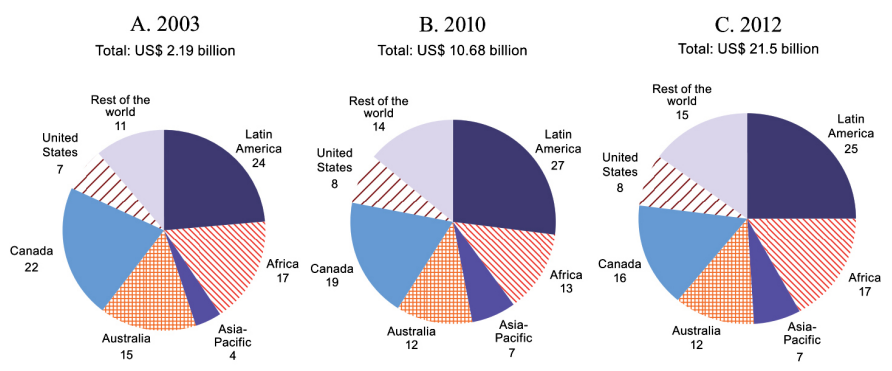

This commodity boom opened up possible space for structural transformation because, for the first time since the 1960s, African governments could access surpluses for reducing debt and investing in infrastructure and diversification. Three recent reports focused on Africa's economic future, highlighting the inherent challenges African governments face in this regard. Both the United Nations Economic Commission for Africa (UNECA) and the African Center for Economic Transformation (ACET) released reports in 2014 that have become highly influential. These reports are Dynamic Industrial Policy in Africa and African Transformation Report, respectively. The third, the United Nations Conference on Trade and Development's (UNCTAD 2012) Economic Development Report, significantly subtitled Structural Transformation and Sustainable Development in Africa, is hardly ever referred to during official African Union events or in the documents on structural transformation emanating from UNECA, ACET, or other African policy think tanks. One can understand all three reports as significant narratives of change, with the first two reflecting mainstream responses to the commodity boom, and the third informing a nonmainstream sustainability perspective that is, however, slowly gaining influence. For example, the theme for the 2016 UNECA annual report is "green industrialization" (see also Africa Progress Panel 2015).

UNECA and African Union's (2014) report argues that Africa's average growth rate between 2009 and 2013 remained $0.6 \%$ below its growth potential of $4.2 \%$ per year. To generate higher growth rates and promote inclusive growth, governments need to reverse the stagnation and decline of the manufacturing sector. Governments need to create and implement industrial policies that overcome the "constraints to economic diversification and development to do this. To finance the necessary investments, Africa needs to tap new sources of finance, especially innovative domestic sources" (UNECA and African Union 2014:29). In line with the new orthodoxy of institutional economics (Evans 2005), the state leads this change strategy: "Institutions and policies are the key instruments for increasing productivity, growth and structural transformation" (UNECA and African Union 2014:31). The report notes that strategies aimed at transforming the economy should also promote high-quality education and health services, which "power greater productivity and more inclusive growth" (UNECA and African Union 2014:29).

The ACET report proposes measuring African progress on a Transformation Index, which fortunately goes beyond per capita gross domestic product (GDP) criteria and includes diversification of productive activities and exports, export competitiveness, agricultural productivity, and human well-being (ACET 2014). The index tracked these and other factors in 21 African countries over two periods, 1999-2001 and 2009-2011 (Fig. 3). The ACET Transformation Index (ATI) is a composite number based on indicators for a large number of sectoral categories. Countries are then ranked against this, with Mauritius ranked as the most advanced economy in terms of the ATI. Mauritius did not change status between reporting periods, but Botswana declined by five points, whereas Rwanda improved by three points.

Both the UNECA and African Union (2014) and ACET (2014) reports concur that governments need to create new institutions to drive industrial policies that will diversify economies through increasing manufacturing and modernizing agriculture. However, both reports ignore the fact that factors such as productivity, technological upgrading, and human well-being are inseparable from wider game-changing dynamics such as rapid urbanization, climate change, and resource depletion. In short, as I will argue, neither considers the nexus between macroeconomic gamechanging dynamics and sustainability-oriented game-changing dynamics. 
Fig. 3. Ranking of African countries based on the African Transformation Index (ATI). The ATI is a composite number based on indicators for a large number of sectoral categories. Shown is the average score for 2009 and 2011. Numbers after country names indicate the change in rank between 2000 and 2010. Source: African Centre for Economic Transformation (2014).

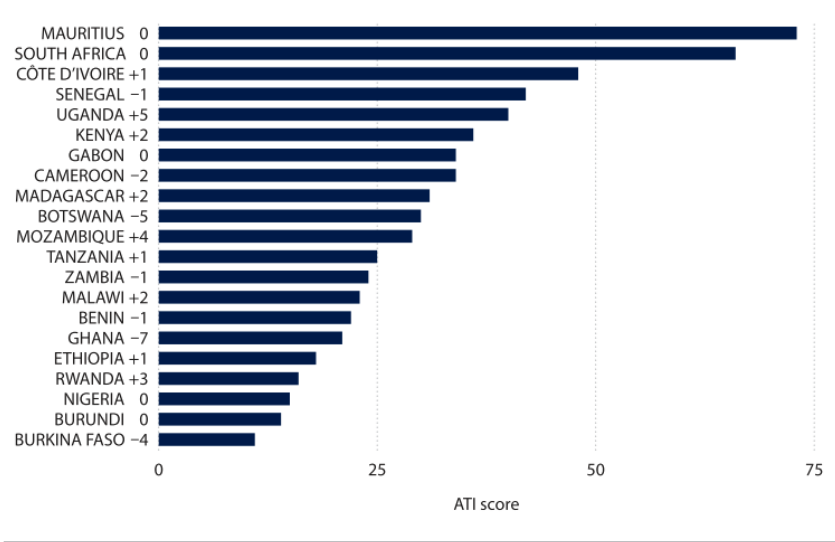

Note: The 2010 score is the average for 2009-11. The numbers after each country name show the change in rank between 2000 and 2010.

Significantly, in this regard, UNCTAD's (2012:26) report calls for a "strategy of sustainable structural transformation" that uses "deliberate, concerted and proactive measures to improve resource efficiencies and mitigate environmental impacts of the growth process." In summary, this requires that a "relative decoupling of resource use and environmental impact from the economic growth process" should accompany structural transformation (UNCTAD 2012:26).

The report moves beyond institutional economics by integrating material flow analysis, which has emerged in recent years from the work of leading ecological economists and the International Resource Panel (Fischer-Kowalski and Haberl 2007, FischerKowalski and Swilling 2011), into an understanding of structural transformation. The report provides empirical evidence on material flow rates to and from the continent; it shows that domestic material extraction increased by $87 \%$ between 1980 and 2008 to 5.3 billion tonnes, with extraction of fossil fuels and minerals increasing faster than other sectors. Africa, according to this analysis, is a net exporter of nonrenewable resources, but a net importer of renewable resources such as biomass. In addition, it exported 500 megatonnes of unrefined fossil fuels and imported 100 megatonnes of refined fuels. Contrary to the popular conception that Africa is primarily an exporter of agricultural products, the continent imports $>$ 6.5-times more biomass (mainly cereals followed by vegetable fats and oils, timber, and sugar crops) than the 14.5 megatonnes of largely unprocessed agricultural products it exports. Africa had the lowest resource productivity (purchasing power parity in USD per weight of resources) in the world in 2008 by a factor of 4 compared to Europe and 0.5 compared to Latin America and Asia (UNCTAD 2012).
Although mainstream policy-oriented documents reach different conclusions taking into account different variables (e.g., UNECA focuses on economic growth, ACET focuses on transformation, and UNCTAD focuses on sustainable resource use), they do share and reflect a general consensus within the African policy community that there is a set of game-changing dynamics that is changing the way African policy makers are anticipating future trajectories of change. The game-changing dynamics that all three reports regard as significant are the following:

- A commodity boom that has stimulated growth rates not seen since the $1960 \mathrm{~s}$;

- The related rise of the so-called "BRICS-plus" countries, which has created a new East-South global economic axis primarily based on extracting and exporting African resources and importing manufactured goods, from China in particular;

- Potential to reverse the long-term decline of the manufacturing sector by reinvesting resource rents and exploiting the potential opened by rising manufacturing costs in China;

- The importance of institutional stabilization of macroeconomic planning and management;

- A rapidly expanding middle class with increased spending capacity, and;

- The risks of increasing dependence on resource rents in a highly volatile commodities market.

These six game-changing dynamics are constructions that have been articulated in these terms by key mainstream policy actors. There are, of course, others referred to in the complex discourses in forums and documents (e.g., shortage of investment capital). However, these six are repeated most often across a wide range of networks, fora, and documentation.

Although there is a wide range of issue-oriented actor networks that engage these mainstream game-changing dynamics (e.g., Development Finance Institutions that promote industrial policies, the Resource Charter that responds to the resource curse, Mo Ebrahim Foundation's sponsoring of a "good governance" discourse), Branch and Mampilly (2015) have recently argued that the wave of uprisings across 40 African countries in recent years is an overarching transformative response to elite accumulation strategies that reproduce poverty and inequality. They argue this is Africa's third wave of uprisings: the first, during the 1950s$1960 \mathrm{~s}$, got rid of colonialism; the second, in the 1980s-1990s, got rid of the dictatorships; and now, the third is underway, with outcomes that cannot be predicted. For the purposes of my discussion, these uprisings seriously question notions of structural transformation that will do little to address poverty and inequality.

\section{Less-recognized game changers}

The six game changers referred to above relate to a relatively narrow economistic conception of Africa's development options. Providing a more comprehensive picture would entail taking into account a much wider set of game-changing dynamics that is not always referred to in mainstream documents or in the discourse of various fora. The game-changing dynamics discussed below 
have emerged as a direct consequence of the 2000-2013 economic boom (e.g., more intense energy demand), as deeper, long-term processes that have become major constraints on development (e.g., soil degradation), or as existing conditions that were accelerated by the boom (e.g., urban slums).

These less-recognized game-changing dynamics are energy infrastructure challenges in a context of climate change, water scarcities, land grabbing and soil degradation, slum urbanism, and food insecurity. They are less recognized because they are not referred to in mainstream policy documents and in the discourses at various mainstream fora as game-changing dynamics. However, they are in reality game-changing dynamics as defined here, but articulated now by policy actors that are focussing on a particular game-changing dynamic rather than on those that enjoy a consensus within the mainstream perspectives (see Table 1 for a summary of less-recognized game changers and corresponding social and system innovation responses).

Table 1. Less-recognized game-changing dynamics and associated social and system innovation responses.

Less-recognized game- Social and system innovation responses changing dynamics

Energy infrastructure International Renewable Energy Agency and the Clean Energy Corridor; iShack with respect to energy poverty

Land grabbing and soil degradation African Organic Network, responding to soil degradation

Slum urbanism

Shack/Slum Dwellers International and iShack

Food insecurity

AFSUN joint initiative between the Southern African Research Centre at Queens University in Canada, the African Centre for Cities at the University of Cape Town in South Africa, and an array of southern African universities and nongovernmental organizations

Water scarcities Not applicable

Energy infrastructure challenges in a context of climate change Africa has to embark on a massive electrification program to meet the demand created by an average 5-7\% economic growth rate each year driven thus far by the commodity boom. The severe lack of infrastructure is a constraint on not only growth, but also economic diversification. Currently, the continent, with $>1$ billion people, has the same installed electricity capacity as France, which has 80 million people. Using fossil fuel-based technologies to produce electricity will breach all global climate mitigation targets (Africa Progress Panel 2015). The world therefore has an interest in African economies investing in renewable energy. This is technically and economically feasible, according to the International Renewable Energy Agency's feasibility assessment for what it has termed the Africa Clean Energy Corridor (International Renewable Energy Agency 2014).

Water scarcities

Africa has 300 major river basins, and most cross national boundaries. Very few have functional governance arrangements.
Most river resources are overexploited and become polluted when passing through urban areas before discharging into the sea. Changes in riverine ecosystems threaten the livelihood prospects of communities dependent on them. There is no comprehensive inventory of Africa's rivers, their pollution status, or their governance structures. It is therefore unsurprising that, from a comparative perspective, Africa has the most vulnerable water supplies, as reflected in the global water vulnerability of supply index (Sonderegger et al. 2015). Structural transformation driven by resource rents generated by the commodity boom will depend on investment in water resources and strong institutional arrangements for managing transboundary river basins. Africa will face mounting socio-political conflicts over access to and quality of water resources if these systems are further degraded (Collins 1990, Turton and Ashton 2008). Accelerated economic growth, re-emerging industrial production, rapid rates of urbanization, and climate change are putting increasing pressure on water resources. Relative water scarcity is, therefore, a gamechanging dynamic that could trigger major political conflict if not addressed by mainstream perspectives.

\section{Land grabbing and soil degradation}

Africa has 187 million ha of agricultural land, 793 million ha of permanent pasture, and 683 million ha of forests and woodlands, according to the International Food Policy Research Institute (Scherr 1999). At least 30\% of this resource is degraded, with more than one-half of that seriously degraded, and significantly, $65 \%$ of agricultural land is degraded (Scherr 1999). Anecdotal evidence points to long-term nutrient mining, deforestation, and continuous expansion onto virgin soils as drivers of this degradation (Scherr 1999). As land degradation intensifies, ruralurban migration will accelerate, negatively affecting food security levels. To double agricultural yields per area of land (NEPAD 2014), governments will have to invest in restoring soils.

While soil degradation is a long-term process and presents a current major challenge in light of the need for economic diversification and growing demand for food, the specific gamechanging dynamic is the rapid increase in land-grabbing rates since the food price spike in 2008. Since then, investors with strong links to their respective national governments and to international markets have been buying up large quantities of African land very cheaply (Cotula et al. 2009, Bringezu et al. 2014).

\section{Slum urbanism}

Based on United Nations population data for the period between 1950 and 2050, the world's urban population is expected to increase from 3.5 billion in 2010 (of which $73 \%$ were living in cities in developing countries) to 7.3 billion in 2050 (by which time $83 \%$ will be living in cities in developing countries; United Nations Department of Economic and Social Affairs 2012).

The urbanization process that began in earnest in 1800 had by 2010 only resulted in the urbanization of $48 \%$ of the households expected to be living in urban settlements by 2050 . Furthermore, the ground-breaking 2003 United Nation's Habitat report Challenge of Slums estimates that of the 3.5 billion urbanites in 2010, 1 billion will live in slums (United Nations Centre for Human Settlements 2003).

Significantly, although one-half of all slum dwellers live in Asian urban settlements, it is only in sub-Saharan Africa that one finds 
cities where the majority of the population lives in slums $(62 \%$ of all urbanites) and most cities are slum cities (United Nations Habitat 2008). Given Africa's high urbanization rates (3.3\%, with a projected urban population of 1.2 billion by 2050; United Nations Habitat 2008:5), expanding slum populations today will ensure that slums are likely to remain a reality into the future.

Africa's urbanization patterns are not new and cannot therefore be presented as a game-changing dynamic; however, the emerging debate about the relationship between African cities and accelerated growth is a new development. Pieterse and Parnell's (2014) seminal book, Africa's Urban Revolution, is a forceful plea that African economic policymakers address this challenge if they want to prevent dysfunctional spaces from undermining economic development and growth. While mainstream thinking has tended to view urban agglomeration as good for growth (World Bank 2009), academic perspectives have suggested that Africa's dysfunctional urban agglomeration patterns are a binding constraint on growth and diversification (Buckley and Kallergis 2014, Turok 2014). It is this, plus accelerated informalized urban expansion since the start of the commodity boom, that constitute slum urbanism as a game-changing dynamic.

\section{Food insecurity}

Food insecurity is a key indicator that the global food system is incapable of responding to current pressures. A wide variety of factors undermine the capacity to ensure food availability. In addition, there is limited focus on how the global food system's structure, which comprises highly concentrated ownership across the value chain, affects food security, which is increasingly understood as resting on access, as opposed to availability (Patel 2008, Godfray et al. 2010). Several factors cause limited and inappropriate access to food, including the inability to buy food, which is often a symptom of limited or irregular income. The recent dramatic increases in food prices exacerbate these income shortfalls, and the resultant erratic, limited, or inappropriate access to food can lead to poor nutrition and other health-related consequences. These consequences affect the cost of public health systems and can potentially cause social unrest.

It is important to distinguish between absolute hunger (experienced in areas beset by conflict or devastated by natural disasters) resulting from absolute shortages of food (i.e., famine) and food insecurity. Emotive images such as Kevin Carter's 1993 Pulitzer Prize-winning photograph of the vulture watching the starving Sudanese child prompt responses of solutions at any cost; these can be inappropriate solutions. Recent interventions such as famine early-warning systems and innovative response strategies are serving to reduce instances of absolute shortages (Casale et al. 2010), whereas food insecurity is a far more nuanced problem (Food and Agriculture Organisation 2013) requiring systemic solutions. Current responses are primarily production orientated (for examples of this perspective see World Bank 2007; Alliance for the Green Revolution in Africa, http://www.agra. org/) and focused on rural areas; they overlook the demographic shift taking place in Africa and the effect of food insecurity within cities.

A production focused absolute shortage perspective is a significant failure with a number of consequences. One consequence is that the scientific and technology-driven focus is on increasing or optimizing net calories (for the best example of this perspective see Borlaug 2000). Another consequence is that often reactive and unfocused welfare interventions are used to mitigate limited access. A third consequence is that policies tend to reinforce this production-welfare paradigm. Such food security responses disregard the current transitions evident within society and fail to recognize that systemic solutions at the local, national, regional, and global scales will be required to address Africa's food insecurity challenges (Hajer et al. 2016).

In summary, the accelerated economic growth caused by the commodity boom and, to some extent, the effects of climate change and resource depletion have catalyzed some processes into game-changing dynamics. These are:

- Increased demand for energy to fuel economic growth, but within a global policy environment committed, in theory, to decarbonization;

- Increased demand for water within a context of global warming, and rapid growth in demand in both agricultural and urban sectors;

- Increased demand for food in the face of rising food prices and degraded soils;

- Accelerated urbanization resulting in expanding slums and dysfunctional spaces for economic growth;

- Increased food insecurity because of the structure of the global food system and the changing rural-urban dynamics of accelerated urbanization.

The commodity boom is the mega-game-changing dynamic driving the overarching need for structural transformation. However, this structural transformation will require more than mere modernization through industrialization. Given the context of a carbon- and resource-constrained world, there will need to be a sustainable transformation brought about, in part, by scalable socio-technical system innovations to address the challenges around energy, water, and soils. I next describe four initiatives that provide social or system innovation responses to these less-recognized game changers. These initiatives are responses by particular networks that invoke these gamechanging dynamics to justify their respective proposals for fundamental system change over the longer term. However, to achieve their longer term goals, three of five initiatives have activated specific social innovations to mobilize specific constituencies: AfroNet's successful network of actors who share a commitment to organic farming, SDI's community-based organizing-for-development approach, and iShack's use of solar power technologies to address energy poverty.

\section{SOCIAL AND SYSTEM INNOVATION RESPONSES}

\section{Shack/Slum Dwellers International in Africa}

Shack/Slum Dwellers International (SDI, http://sdinet.org/ about-us/what-we-do/) comprises community-based organizations of the urban poor in 33 countries in Africa, Asia, and Latin America. It originated in anti-eviction struggles in Mumbai, India and Cape Town, South Africa in the early 1990s. Formalized in 1996 and supported by an international network of countrybased nongovernmental organizations (NGOs), it has built up federations in 19 African countries. This new "developmental" 
movement represents the coalescing of pre-existing movements with structures at the local, regional, national, and international levels, and a particular approach to community-driven urban development (a set of methodologies), illustrating an embryonic theory of self-organized, community-based development. It increasingly includes an emerging set of effective urban social movements.

SDI's structure is typically self-managed savings and loans groups comprising between 20 and 50 people who learn how to use a particular methodology to collect savings and loan repayments on a daily basis and how to make loans to members. Federations of savers are then constituted at the city, regional, and national levels. An identifiable leadership grouping emerges at all levels. Formally constituted and structured NGOs are constituted to support the federations. These NGOs are located in each country and staffed mostly by professionals with the ability to apply the learning methodologies, initiate and facilitate grassroots community organization around savings and loans, and provide technical support for projects and negotiations with other stakeholders. A nationally constituted bulk-funding mechanism is then created to capture donor and state funding and disburse funds to savings and loans groups.

SDI's methods combine savings and loans with learning and community development strategies. The savings and loans model eschews high-cost and top-down control models and redirects financial flows within communities, builds social solidarities and trust, and channels development funds into communities. SDI trains members to manage survey-based enumeration processes to enable the community to control knowledge about itself and engage with outsiders more effectively. Exchange programs are arranged to allow local leaders to visit each other across cities, regions, and countries to enable peer-to-peer learning and deepen self-understanding through new experiences. House modeling is a simple technique for building mock houses to rally popular community attention to a process that promises tangible proof of change. Negotiating and deal making is the most controversial and counterintuitive of all the methods because of the emphasis on direct engagement with, in particular, state agencies to make demands, reach agreements, and co-create implementation mechanisms. When states have low levels of legitimacy, which occurs in most places in Africa, the organization is often accused of reformism, co-option, and doing the state's work. However, the critics of radical pragmatism do not realize that engagement forces communities to clarify exactly what they want, and hones the skills of leaders, who soon realize that what they get at the negotiating table depends on the strength of their organizational formations on the ground. In addition, concessions help sustain the long-term commitment of large membership-based groups by presenting them with the rewards of continued organization.

Many local and national governments in sub-Saharan Africa recognize and collaborate in some form with SDI affiliates, which has resulted in some local social innovations being scaled up to the city level. Sustained social innovations, initiated by affiliates, have in many places transformed the relationships between slum/ shack dwellers and the city in which they reside. Social innovations rest on the assumption that community-based incremental upgrading is the most effective way of managing rapid urbanization in a context of weak urban governance systems. The resultant modes of service delivery are not dependent on centralized, formal, bureaucratic infrastructure delivery networks. As such, they are potentially transformative social innovations with significant implications for governance, resourcing, and social learning.

\section{African Food Security Network}

AFSUN is a joint initiative between the Southern African Research Centre at Queens University in Canada, the African Centre for Cities at the University of Cape Town in South Africa, and an array of southern African universities and NGOs. It is also supported by the Municipal Development Partnership for Eastern and Southern Africa and South African Cities Network.

The initiative, started in 2008, focuses on food insecurity in Africa's rapidly expanding towns and cities. In particular, it examines the nexus between dysfunctional global food systems and rapid, largely informal, urbanization processes. It is significant in that it generates new research that systematically addresses issues that are not addressed at policy and urban planning levels. It represents a socially innovative way of generating agenda-setting, research-based narratives that are beginning to trigger policy-orientated system change.

The AFSUN network has generated case studies on urban food systems in Maputo, Lusaka, Blantyre, Gaborone, Johannesburg, and Cape Town, among other cities, and has produced reports on cross-cutting themes related to food security. The most significant report was a special edition of the journal Urban Forum, with 10 papers examining urban food deserts from different angles. The concept, applied since the mid-1990s to economically disadvantaged areas in European and North American cities, where residents have relatively poor access to healthy and affordable food because of a lack of modern retail outlets, has not yet been applied systematically to the cities of the global South. However, these cities contain poor neighborhoods with residents who are far more food insecure and malnourished than their northern counterparts. Using this concept in an African city context needs a more sophisticated understanding of overlapping market and nonmarket food sources, the dynamism of the informal food economy, differing experiences of food insecurity between households, and the specific African conditions that lead to compromised diets, undernutrition, and social exclusion (Battersby and Crush 2014).

AFSUN's collaborative, interdisciplinary research on food systems in crisis has subverted the notion that food is merely a commodity regulated by market forces. It actively uses its research to engage with people operating in the food system, partly as agenda-setting exercises, but also to build networks and prompt innovations within the system to bring about change. This engagement is done via a series of stakeholder workshops that intentionally link the system research that has been done to the kind of transformation research that might be required to achieve the normative goals of the network.

\section{Africa Clean Energy Corridor}

It is commonly accepted that if Africa's average GDP growth to 2030 continues at the current rate, the installed electrical generation capacity will need to increase by more than double. This means increasing annual output from just $>600$ TWh to just $<1600$ TWh by 2030. Africa generates most of its energy from 
fossil fuels and hydro-power. Biomass plays a key role in rural and urban household generation. The International Renewable Energy Agency notes that the current continent-wide focus on structural transformation provides a unique opportunity for Africa to invest in large-scale renewable energy sources (Fig. 4). It argues that this investment would "be economically competitive with other solutions, would unlock economies of scale, and would offer substantial benefits in terms of equitable development, local value creation, energy security, and environmental sustainability" (International Renewable Energy Agency 2013:Preface). This view was repeated by the Africa Progress Panel led by Koffi Anan (Africa Progress Panel 2015) and then formalized in the launch at COP21 in Paris in December 2015 of the Africa Renewable Energy Initiative (African Union 2015).

Fig. 4. Distribution of identified renewable energy potential in Africa. Source: International Renewable Energy Agency (2013), based on the Global Atlas.

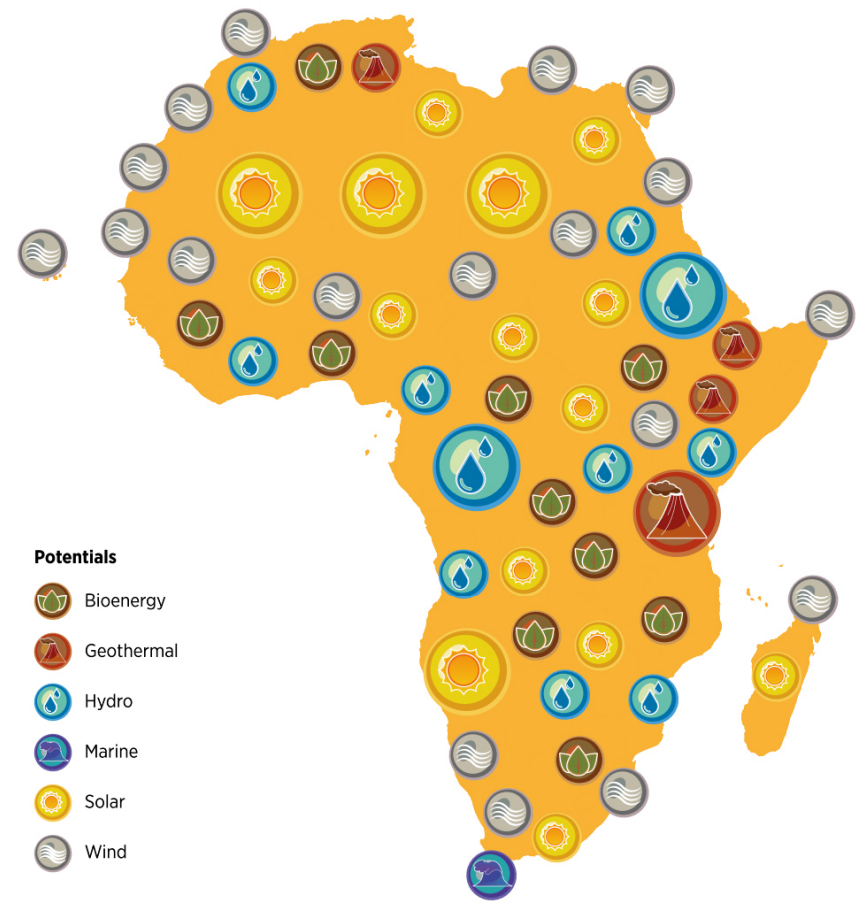

Despite the African Union's energy strategy focusing on hydro and fossil-fuel power generation, 46 African countries adopted the Abu Dhabi Communique on Renewable Energy for Accelerating Africa's Development in 2011. The International Renewable Energy Agency developed the Renewable Energy Scenario for Africa to support this. The scenario examines what effects policies actively promoting this transition would have by 2030; it projects that renewable energy as a share of total output would increase from $17 \%$ in 2009 to $50 \%$ by 2030 and nearly $75 \%$ by 2050 . The scenario is based on universal access by 2030 and on reduction of life-cycle costs of renewables compared to a fossil fuel-based business-as-usual scenario.

In 2013, the International Renewable Energy Agency published Africa's Renewable Future: the Path to Sustainable Growth, which, following an executive strategy workshop with regional governance bodies, African power pool representatives, multilateral financial institutions, and development partners, laid the groundwork for its 2014 report Africa Clean Energy Corridor: Analysis of Infrastructure for Renewable Power in Southern Africa. The latter report reflects key decisions taken at the workshop around formally institutionalizing the corridor in decisionmaking and governance structures. The International Renewable Energy Agency has effectively put in place a consensus framework for sustainability-orientated system innovation by using the need for structural transformation to create policy space for the renewable agenda.

There is rapid growth occurring in renewable energy projects in Africa (Africa Progress Panel 2015). This growth rests in part on the competitive pricing of renewable energy with fossil fuel-based energy, but is also driven by supportive international finance flows derived from concern about global climate targets (African Union 2015).

It remains to be seen whether African governments will overcome the tendency to favor tried-and-tested technologies over sustainability-orientated initiatives. The outcome might be influenced by major emerging investors who recognize the advantage offered to Africa by renewables during the post-COP21 era (African Union 2015). The various sovereign wealth funds being established in Africa and elsewhere drive large-scale change in this particular policy space (Bolton et al. 2012). The International Renewable Energy Agency operates in a gamechanging space where its work could result in transformative system change, particularly related to governance issues.

\section{African Organic Network}

The Second African Organic Conference, held in May 2012 in Zambia, was the culmination of an extraordinary and long-term collaboration between government decision makers, organic farming movements, civil society groups, scientists, and international agencies that share the belief that organic agricultural practices can increase productivity while improving livelihoods and food security, and can also contribute to conserving plant and animal diversity and indigenous knowledge while building resilience to climate change effects (Auerbach et al. 2013). This coalition directly connected its own narratives to the wider game-changing dynamics of degrading soils and food insecurity within a context of climate change and structural transformation.

Conferences held in 2008 and consistent work by organic networks and development partners led to the passing of the African Union Decision on Organic Farming and provided the policy foundation for the Second African Organic Conference (Auerbach et al. 2013). The outcome was the agreement to establish the African Organic Network (AfroNet). Up until this point, networks of individuals, most of them deeply rooted in localized agro-ecological social innovations as farmers, support agency employees, or government officials, had held the organic movement together. AfroNet represents a solid and wellsupported narrative around agro-ecological farming that is inclusive and now enjoys support from the continent's leading bodies such as the African Union. Its innovative work rests on and leads to increased social learning. 


\section{Learning from the iShack project}

Soon after 1994, the South African government introduced an ambitious housing program to address the legacy of apartheid. It constructed 2.9 million houses by 2010 , one of the highest rates of housing delivery to the poor in the world. Nevertheless, shrinking household sizes and population growth meant that by 2004, the housing backlog had grown from 1.5 million to 2.1 million units. To make matters worse, to reduce costs, houses were built on cheap land on the urban peripheries far from places of employment and access to services. This resulted in the ballooning of bus transport subsidies and exacerbated household poverty in these settlements (Khan 2008).

To remedy this problem, the Department of Human Settlements introduced a new housing policy in 2004 called Breaking New Ground: a Comprehensive Plan for the Development of Sustainable Human Settlements. A key component of the plan was acceptance that informal settlements would need to be upgraded in situ as opposed to relocated. Upgrading is undertaken through the Upgrading of Informal Settlements Programme. The department committed to upgrading 400,000 shacks by 2014 (Swilling et al. 2016)

In early 2011, a group of postgraduate students at Stellenbosch University, South Africa decided to focus their research on Enkanini (meaning "take by force"), an illegal informal settlement of 6000 people located within walking distance of the town (Keller 2012, Swilling et al. 2016). The initial research question was: What does in situ upgrading (as specified by government program) mean in practice from the perspective of the average shack dweller living in Enkanini?

The group adopted a transdisciplinary research approach, which requires engagement with representative stakeholders in a community. This was not possible in Enkanini because no such structures existed, and the students instead had to establish direct relationships, moving into the community to experience what it means to live in a shack, mounting visible campaigns such as painting shacks, and building relationships with individuals. The team made contact with the Informal Settlement Network, a social movement in the area supported by SDI, and established a working relationship of sorts with officials at Stellenbosch Municipality, who were also working formally with the network.

It became apparent that, in practice, the upgrading program meant municipal delivery of electricity for streetlights (not individual connections to each household and dependent on funding from higher levels of government), water, sanitation, roads, stormwater, and solid waste services. However, delivery was contingent upon two conditions: the settlement was recognized legally as a permanent one, and the land on which it was located was zoned residential. Enkanini met neither of these conditions; it remains one of the few informal settlements with a court interdict ruling for its removal, although this has not been carried out. Even if conditions were met in Enkanini, upgrading means waiting for the electricity and water grids to arrive, with minimal solid-waste collection services in the meantime. According to the Western Cape Provincial Government, this process takes about eight years following legalization and rezoning. The research question shifted to become: What could be done between now and the arrival of the grids to improve quality of life?
Development has come to mean "trust and wait," effectively demobilizing civil society because there is nothing to organize communities around that can result in tangible, immediate improvements to daily life. The transformation-orientated research question becomes significant in this context. Conventional questions aim primarily to establish systems knowledge (e.g., Why does the settlement exist? What are the living conditions?) and sometimes target knowledge (How can the infrastructure delivery system be improved?). Asking what can be done now by members of the community aims to generate transformation knowledge that will result in social innovations, with implications for system innovation. The research thus generated a new narrative of incremental upgrading (Swilling et al. 2016).

After months of informal interactions with the community, various community networks, and municipal officials, an ecological design method was adopted as a way of opening up an alternative way of thinking about genuine incremental upgrading approaches that avoid the negative consequences of "trust and wait." An "improved shack" of $14.2 \mathrm{~m}^{2}$ (which became known as the iShack) was designed, incorporating fire-retardant insulation, passive heating and cooling materials, orientation to maximize solar penetration, a solar panel, and a gutter to capture rain water. Local and reclaimed materials were used as far as possible.

The first iShack was built for a single mother with three young children. Her old shack was demolished as required by the municipality. The team retrofitted a neighboring shack for insulation and installed a solar unit. These two shacks plus a nonretrofitted shack were monitored for comparative purposes. The intervention provided $4-6 \mathrm{~h}$ of extra thermal comfort each day, reduced fire risks, and improved lighting (Keller 2012). The team also began research into sanitation and solid-waste issues.

This research-based intervention set in motion a process of social mobilization within the community around demands for incremental upgrading. The involved community members accumulated skills and knowledge, including formal training. What started off as a rather limited technical intervention spiralled out into a wider community-based, social-innovation process. The Bill and Melinda Gates Foundation provided a \$250,000 USD grant in 2012, and the South African government's Green Fund allocated a further $\$ 1.7$ million USD to take the project to scale. In 2013, Stellenbosch Municipality amended its indigent policy to provide nongrid-connected shack dwellers with the free basic electricity subsidy. This is an unprecedented system innovation with national implications for other informal communities. In 2014, SDI's global leadership announced that it would like to incorporate the iShack approach into the strategic offerings of all its African affiliates.

Driven by problem-solving research, the envisaged end result is a viable social enterprise that makes it possible to organize informal settlements around tangible material improvements, for which they pay a fee in return for guaranteed services. Once the community realizes the benefits of cooperative action, it will have in place social and institutional structures that make it possible to continue to advocate for further improvements such as secure land rights. 
It was the technical breakthroughs about alternative infrastructure solutions, derived from interactions with particular groups of shack dwellers, which produced the social effects, including final recognition by decision makers that Enkanini was there to stay. In short, a limited, well-managed process triggered a secondary and much wider transformation involving a set of political players who were not initially involved.

\section{CONCLUSION}

I began with an overview of mainstream and less-recognized game-changing dynamics. Mainstream thinking regards structural transformation of African economies as the overriding priority, and there is overwhelming consensus among African stakeholders, major international agencies, and popular business media that Africa will be the next region to join the modernization bandwagon. This focus, however, neglects less-recognized, but still significant, game-changing dynamics related to energy, water, soils, food systems, and urbanization. These dynamics are longstanding socioeconomic and ecological challenges that are derivatives of structural transformation and will shape the direction of structural transformation.

I discussed various African-based actor-networks that have responded to the mainstream and less-recognized game changers in various ways. These responses involve a mix of social and system innovations. These responses, however, cannot be understood in a deterministic way as the effects of changing structural conditions. These Africa-based actor-networks have both responded to the game-changing dynamics and actively shaped the narratives that have evolved to understand these gamechanging dynamics to justify their own social or system innovation.

The role and mode of research will need to change if we are interested in connecting game-changing dynamics to transformative social innovations. The merging of transdisciplinarytype thinking with indigenous research methods has resulted in a mode of research and social learning that can play an active role in catalyzing, fostering, and promoting transformative social innovations. The case study of the iShack initiative was used to illustrate this line of argument. By contrast, SDI affiliates either host researchers arriving with preformulated problem statements and research questions or they formulate their own questions and appoint researchers as consultants. Problems are not coformulated by researchers and the community, limiting the potential to co-produce new knowledge. AFSUN conducts research that primarily produces system knowledge and relatively weak sets of target knowledge; however, despite its well-facilitated workshops and resultant generated knowledge, it does not publicize this, indicating a blind spot regarding transformation knowledge, or at least making this aspect of its knowledge enterprise explicit. The International Renewable Energy Agency's researchers are embedded in formal governance structures and they collaborate significantly with decision makers to co-produce target and transformation knowledge. The agency, however, appears to predetermine its own problem statements and research questions given the weak commitment to nonhydro renewables in energy planning in Africa. Perhaps investing sufficient time in coproducing the problem statements and research questions with stakeholders could result in high-impact transformative social innovations. AfroNet is an intriguing example of a semi-formal network that has developed a shared understanding of the underlying problem statement and is fast formalizing itself into a "network of networks" with a clear commitment to generating target knowledge. Because they deploy all their resources for this purpose, they run the risk of ignoring the importance of investing systematically in the kind of transformation knowledge that has energized the movement up until this point.

To return to the quote by Bruno Latour, if we are to break the paralyzing trance that immobilizes us in the face of an "apocalypse in slow motion", we will have to find a mode of analysis that avoids pitting the limits of individual and collective action against the power of structural contradictions depicted as trajectories beyond the reach of human agency. This is what causes the "frenetic snail's pace" that every international conference on sustainability bemoans. While passion for such change is needed, it is at best Quixotic without analysis that endogenizes these seemingly unreachable structural contradictions into the dynamics of everyday politics. A strategic analysis of the intimate connections between transdisciplinary knowing, social innovations, wider transformations, and "glocal" game-changing dynamics may well provide a fruitful way beyond the age-old structure-agency impasse responsible for the persistent snail's pace of change.

Responses to this article can be read online at: http://www.ecologyandsociety.org/issues/responses. $\mathrm{php} / 8226$

\section{Acknowledgments:}

Funding for this research was provided by the National Research Foundation and the Dutch Research Institute for Transitions.

\section{LITERATURE CITED}

Africa Progress Panel. 2015. Power people planet: seizing Africa's energy and climate opportunities. Africa Progress Panel, Geneva, Switzerland. [online] URL: http://www.africaprogresspanel.org/ wp-content/uploads/2015/06/APP_REPORT_2015 FINAL_low1. pdf

African Center for Economic Transformation (ACET). 2014. 2014 African transformation report: growth with depth. African Center for Economic Transformation, Accra, Ghana. [online] URL: http://acetforafrica.org/wp-content/uploads/2014/03/2014African-Transformation-Report.pdf

African Union. 2015. Africa renewable energy initiative. African Union, Addis Ababa, Ethiopia.

Anderson, T., A. Curtis, and C. Wittig. 2014. Definition and theory in social innovation. Thesis. Danube University, Krems, Austria. [online] URL: http://www.social-innovation-blog.com/wp-content/ uploads/2014/05/Definitions-and-Theory-in-Social-Innovation-Final-1. pdf

Auerbach, R., G. Kundren, and N. E. Scialabba, editors. 2013. Organic agriculture: African experiences in resilience and sustainability. Food and Agriculture Organization, Rome, Italy. [online] URL: http://www.fao.org/docrep/018/i3294e/i3294e.pdf 
Avelino, F., J. Wittmayer, A. Haxeltine, R. Kemp, T. O'Riordan, P. Weaver, D. Loorbach, and J. Rotmans. 2014. Game-changers and transformative social innovation: the case of the economic crisis and the new economy. TRANSIT working paper. EU SSH.2013.3.2-1, grant agreement 613169. DRIFT, Rotterdam, The Netherlands. [online] URL: http://www.transitsocialinnovation. eu/content/original/

TRANSIT $\% 20$ outputs $/ 91 \% 20$ Gamechangers_TSI_Avelino_eta1 TRANSIT workingpaper 2014.pdf

Battersby, J., and J. Crush. 2014. Africa's urban food deserts. Urban Forum 25(2):143-151.

Bolton, P., F. Samana, and J. E. Stiglitz, editors. 2012. Sovereign wealth funds and long-term investing. Columbia University Press, New York, New York, USA.

Borlaug, N. E. 2000. Ending world hunger. The promise of biotechnology and the threat of antiscience zealotry. Plant Physiology 124(2):487-490. http://dx.doi.org/10.1104/pp.124.2.487

Branch, A., and Z. Mampilly. 2015. African uprising: popular protest and political change. Zed Books, London, UK.

Bringezu, S., H. Schütz, W. Pengue, M. O’Brien, F. Garcia, R. Sims, R. W. Howarth, L. Kauppi, M. Swilling, and J. Herrick. 2014. Assessing global land use: balancing consumption with sustainable supply. United Nations Environment Programme, Nairobi, Kenya. [online] URL: http://www.unep.org/resourcepanel/ Portals/50244/publications/Full_Report-Assessing_Global_Land UseEnglish \%28PDF $\% 29 . p d f$

Buckley, R., and A. Kallergis. 2014. Does Africa urban policy provide a platform for sustained economic growth? Pages 173-190 in S. Parnell and S. Oldfield, editors. Routledge handbook on cities of the global south. Routledge, New York, New York, USA.

Casale, M., S. Drimie, T. Quinlan, and G. Ziervogel. 2010. Understanding vulnerability in southern Africa: comparative findings using a multiple-stressor approach in South Africa and Malawi. Regional Environmental Change 10(2):157-168. http://dx. doi.org/10.1007/s10113-009-0103-y

Chilisa, B. 2012. Indigenous research methodologies. Sage, Thousand Oaks, California, USA.

Collins, R. O. 1990. The waters of the Nile: hydropolitics and the Jonglei Canal. Clarendon Press, Oxford, UK.

Cotula, L., S. Vermeulen, R. Leonard, and J. Keeley. 2009. Land grab or development opportunity? Agricultural investment and international land deals in Africa. International Instituted for Environment and Development, Food and Agriculture Organization, and International Fund for Agricultural Development, London, UK, and Rome, Italy. [online] URL: http://www.ifad.org/pub/land/land grab.pdf

Economic Commission for Latin America and the Caribbean. 2013. Natural resources: status and trends towards a regional development agenda in Latin America and the Caribbean. United Nations, Santiago, Chile. [online] URL: http://hdl.handle. net/11362/35892

Ernst \& Young. 2011. It's time for Africa: Ernst \& Young's 2011 Africa attractivness survey. Ernst \& Young, London, UK. [online] URL: http://www.ey.com/ZA/en/Issues/Business-environment/2011Africa-attractiveness-survey
Evans, P. 2005. The challenges of the "institutional turn": new interdisciplinary opportunities in development theory. Pages 90-116 in V. Nee and R. Swedberg, editors. The economic sociology of capitalism. Princeton University Press, Princeton, New Jersey, USA.

Fischer-Kowalski, M., and H. Haberl, editors. 2007. Socioecological transitions and global change: trajectories of social metabolism and land use. Edward Elgar, Cheltenham, UK. http:// dx.doi.org/10.4337/9781847209436

Fischer-Kowalski, M., and M. Swilling. 2011. Decoupling natural resource use and environmental impacts from economic growth. United Nations Environment Programme, Paris, France. [online] URL: http://www.unep.org/resourcepanel/decoupling/files/pdf/ Decoupling Report English.pdf

Food and Agriculture Organization. 2013. The state of food and agriculture 2013: better systems for better nutrition. Food and Agriculture Organization, Rome, Italy. [online] URL: http://www. fao.org/docrep/018/i3300e/i3300e00.htm

Franz, H.-W., J. Hochgerner, and J. Howaldt, editors. 2012. Challenge social innovation: potentials for business, social entrepreneurship, welfare and civil society. Springer, Berlin, Germany. http://dx.doi.org/10.1007/978-3-642-32879-4

Godfray, H. C. J., I. R. Crute, L. Haddad, D. Lawrence, J. F. Muir, N. Nisbett, J. Pretty, S. Robinson, C. Toulmin, and R. Whiteley. 2010. The future of the global food system. Philosophical Transactions of the Royal Society B 365(1554):2769-2777. http:// dx.doi.org/10.1098/rstb.2010.0180

Grin, J., J. Rotmans, J. Schot, F. Geels, and D. Loorbach. 2010. Transitions to sustainable development: new directions in the study of long term transformative change. Routledge, New York, New York, USA.

Hajer, M., H. Westhoek, L. Ozay, J. Ingram, and S. van Berkum. 2016. Food systems and natural resources. Report for the International Resource Panel. United Nations Environment Programme, Paris, France. In press.

Haxeltine, A., F. Avelino, J. Wittmayer, R. Kemp, P. Weaver, J. Backhaus, and T. O'Riordan. 2013. Transformative social innovation: a sustainability transitions perspective on social innovation. Pages 2-19 in NESTA, editor. Social frontiers. NESTA, London, UK. http://www.scribd.com/doc/191799102/ Transformative-social-innovations-A-sustainability-transition-perspectiveon-socialinnovation

Hirsch-Hadorn, G., D. Bradley, C. Pohl, S. Rist, and U. Wiesmann. 2006. Implications of transdisciplinarity for sustainability research. Ecological Economics 60(1):119-128. http://dx.doi.org/10.1016/j.ecolecon.2005.12.002

Hirsch-Hadorn, G., H. Hoffmann-Riem, S. Biber-Klemm, W. Grossenbacher-Mansuy, D. Joye, C. Pohl, U. Wiesmann, and E. Zemp, editors. 2008. Handbook of transdisciplinary research. Springer, Dordrecht, The Netherlands. http://dx.doi. org/10.1007/978-1-4020-6699-3

International Monetary Fund. 2011. Regional economic outlook: sub-Saharan Africa: recovery and new risks. International Monetary Fund, Washington, D.C., USA. [online] URL: https:// www.imf.org/external/pubs/ft/reo/2011/afr/eng/sreo0411.htm 
International Renewable Energy Agency. 2013. Africa's renewable future: the path to sustainable growth. International Renewable Energy Agency, Abu Dhabi, United Arab Emirates. [online] URL: http://www.irena.org/documentdownloads/publications/ africa renewable future.pdf

International Renewable Energy Agency. 2014. Africa clean energy corridor: analysis of infrastructure for renewable power in southern Africa. International Renewable Energy Agency, Abu Dhabi, United Arab Emirates. [online] URL: http://www.irena. org/DocumentDownloads/Publications/ACEC \%20Document $\% 20$ V19For $\% 20$ Web $\% 20$ Viewing-Small.pdf

Keller, A. 2012. Conceptualising a sustainable energy solution for in situ informal settlement upgrading. Thesis. Stellenbosch University, Stellenbosch, South Africa. [online] URL: http:// www.sustainabilityinstitute.net/si-library/4002-conceptualising-asustainable-energy-solution-for-in-situ-informal-settlement-upgrading

Khan, F. 2008. Political economy of housing policy in South Africa, 1994-2004. Dissertation. Stellenbosch University, Stellenbosch, South Africa.

Lang, D. J., A. Wiek, M. Bergmann, M. Stauffacher, P. Martens, P. Moll, M. Swilling, and C. J. Thomas. 2012. Transdisciplinary research in sustainability science: practice, principles, and challenges. Sustainability Science 7(S1):25-43. http://dx.doi. org/10.1007/s11625-011-0149-X

Latour, B. 2010. Where are the passions commensurate with the stakes? IDDRI SciencePo: Annual Report 2010. Institute for Sustainable Development and International Relasions, Paris, France.

Monitor Group. 2009. Africa: from the bottom up: cities, economic growth, and prosperity in sub-Saharan Africa. Monitor Group, Johannesburg, South Africa.

Moulaert, F., D. MacCullum, A. Mehmood, and A. Hamdouch, editors. 2013. International handbook on social innovation: collective action, social learning and transdisciplinary research. Edward Elgar, Cheltenham, UK. http://dx.doi.org/10.4337/978$\underline{1849809993}$

Muhar, A., J. Visser, and J. van Breda. 2013. Experiences from establishing structured inter- and transdisciplinary doctoral programs in sustainability: a comparison of two cases in South Africa and Austria. Journal of Cleaner Production 61:122-129. http://dx.doi.org/10.1016/j.jclepro.2013.07.031

Mulgan, G. 2006. The process of social innovation. Innovations 1(2):145-162. http://dx.doi.org/10.1162/itgg.2006.1.2.145

Murray, R., J. Caulier-Grice, and G. Mulgan. 2010. Open book of social innovation. Young Foundation and NESTA, London, UK. [online] URL: http://youngfoundation.org/publications/theopen-book-of-social-innovation/

New Partnership for African Development (NEPAD). 2014. Agriculture in Africa: transformation and outlook. African Union, Addis Ababa, Ethiopia. [online] URL: http://www.un.org/en/ africa/osaa/pdf/pubs/2013africanagricultures.pdf

Parnell, S., and E. Pieterse, editors. 2014. Africa's urban revolution. Zed Books, London, UK.
Patel, R. 2008. Stuffed and starved. Melville House, New York, New York, USA.

Regeer, B. J., and J. F. G. Bunders. 2009. Knowledge co-creation: interaction between science and society: a transdisciplinary approach to complex societal issues. RMNO, Amsterdam, The Netherlands. [online] URL: http://www.managingforimpact.org/ sites/default/files/resource/bunders regeer 2009 knowledge cocreation1 tcm19-355212.pdf

Roxburgh, C., N. Dörr, A. Leke, A. Tazi-Riffi, A. van Wamelen, S. Lund, M. Chironga, T. Alatovik, C. Atkins, N. Terfous, and T. Zeino-Mahmalat. 2010. Lions on the move: the progress and potential of African economies. McKinsey Global Institute, London, UK. [online] URL: http://http://www.mckinsey.com/ insights/africa/lions on the move

Scherr, S. 1999. Soil degradation: a threat to developing-country food security by 2020? Food, Agriculture and the Environment Discussion Paper 63. International Food Policy Research Institute, Washington, D.C., USA. [online] URL: http://www. ifpri.org/sites/default/files/publications/pubs $2020 \mathrm{dp}$ dp27.pdf

Scholz, R. W., and O. Tietje. 2002. Embedded case study methods: integrating quantitative and qualitative knowledge. Sage, Thousand Oaks, California, USA.

Sonderegger, T., S. Pfister, and S. Hellweg. 2015. Criticality of water: aligning water and mineral resources assessment. Environmental Science and Technology 49(20):12315-12323. http://dx.doi.org/10.1021/acs.est.5b02982

Swilling, M. 2014. Rethinking the science-policy interface in South Africa: experiments in knowledge co-production. South African Journal of Science 10(5/6):Art.\#2013-0265. http://dx.doi. org/10.1590/sajs.2014/20130265

Swilling, M., L. Tavener-Smith, A. Keller, V. von der Heyde, and B. Wessels. 2016. Rethinking incremental urbanism: coproduction of incremental informal settlement upgrading strategies. In M. van Donk, T. Gorgens, and L. Cirolia, editors. Pursuing partnership-based approaches to incremental upgrading in South Africa. Jacana, Johannesburg, South Africa. In press.

Turok, I. 2014. Linking urbanisation and development in Africa's economic revival. Pages 60-81 in S. Parnell and E. Pieterse, editors. Africa's urban revolution. Zed Books, London, UK.

Turton, A. R., and P. J. Ashton. 2008. Basin closure and issues of scale: the southern African hydropolitical complex. International Journal of Water Resources Development 24(2):305-318. http://dx. doi.org/10.1080/07900620701723463

United Nations Centre for Human Settlements. 2003. The challenge of slums: global report on human settlements. Earthscan, London, UK.

United Nations Conference on Trade and Development (UNCTAD). 2012. Economic development in Africa: report 2012: structural transformation and sustainable development in Africa. United Nations Conference on Trade and Development, Geneva, Switzerland. [online] URL: http://unctad.org/en/PublicationsLibrary/ aldcafrica2012 embargo en.pdf

United Nations Department of Economic and Social Affairs. 2012. World urbanization prospects: the 2011 revision. United 
Nations, New York, New York, USA. [online] URL: http://www. un.org/en/development/desa/population/publications/pdf/urbanization/ WUP2011 Report.pdf

United Nations Economic Commission for Africa (UNECA) and African Union. 2014. Dynamic industrial policy in Africa: economic report on Africa. United Nations Commission for Africa, Addis Ababa, Ethiopia. [online] URL: http://www.uneca. org/sites/default/files/PublicationFiles/final era2014 march25 en. pdf

United Nations Habitat. 2008. The state of African cities 2008: a framework for addressing urban challenges in Africa. United Nations Human Settlements Programme(UN-Habitat), Nairobi, Kenya. [online] URL: http://mirror.unhabitat.org/pmss/listItemDetails. aspx?publication ID $=2574$

World Bank. 2007. World development report 2008: agriculture for development. World Bank, Washington, D.C., USA. [online] URL: http://siteresources.worldbank.org/INTWDRS/

Resources/477365-1327599046334/8394679-1327614067045/

WDROver2008-ENG.pdf

World Bank. 2009. World development report 2009: shaping economic geography. Oxford University Press, Oxford, UK. [online] URL: http://siteresources.worldbank.org/INTWDRS/ Resources/477365-1327525347307/8392086-1327528510568/

PartTwo web full.pdf

World Bank. 2011. Africa's future and the World Bank's support to it. World Bank, Washington, D.C., USA. [online] URL: http:// siteresources.worldbank.org/INTAFRICA/Resources/

AFR Regional Strategy 3-2-11.pdf 